

EKONOMIA I PRAWO. ECONOMICS AND LAW

Volume 20, Issue 2, June 2021

p-ISSN 1898-2255, e-ISSN 2392-1625

www.economicsandlaw.pl

EKONOMIA I PRAWO
ECONOMICS AND LAW

ORIGINAL ARTICLE

received 30.04.2021; revised 20.06.2021; accepted 30.06.2021

Citation: Frydrych, S. (2021). Green bonds as an instrument for financing in Europe. Ekonomia

i Prawo. Economics and Law, 20(2), 239-255. https://doi.org/10.12775/EiP.2021.014.

\title{
Green bonds as an instrument for financing in Europe
}

\author{
SYLWIA FRYDRYCH \\ SGH Warsaw School of Economics, Collegium of Finance and Management, Institute of Risk \\ and Financial Markets, al. Niepodległości 162, 02-554 Warsaw, Poland \\ ๑ sylwia.frydrych@sgh.waw.pl \\ (D) orcid.org/0000-0002-1215-4950
}

\begin{abstract}
Motivation: The interest in sustainable, socially, environmentally and climatically stable development of the economy is growing. At the same time, issuers and investors are looking for financial instruments with which they can achieve their investment goals. The idea of the green bond market is to develop debt instruments in financing projects contributing to ecologically sustainable development, which should have a direct impact on the de-

velopment of technologies and practices in the area of resource use that contribute to limiting adverse climate change. Bonds for financing or refinancing renewable energy sources and increasing energy efficiency are seen as a natural part of the transformation of the global economy.

Aim: The purpose of the article is to present an analysis and goals of green bond market in Europe based on currency of issue, geographic structure, issue period, sectors and issue targets as well as major stock exchanges on which green bonds are listed.

Results: Relevant data on the green bond market in Europe was analyzed and the objectives of issuing green debt finance in particular sectors by number of emission were identified. It was verified that green bonds, which are listed only on one stock exchange, mainly the Scandinavian one, have a lower average value of the issue.
\end{abstract}

Keywords: green bonds; green financing; green bond market

JEL: E44; G10; G15 


\section{Introduction}

The interest in sustainable, socially, environmentally and climatically stable development of the economy is growing, however the current level of investment is insufficient to prevent adverse climate change.

During the Paris climate conference in December 2015, a global action plan was defined the goal of which is to prevent adverse climate changes through the limitation of global warming to the level below $2^{\circ} \mathrm{C}$ (European Commission, 2015). Fulfillment of commitments related to the climate improvement cannot be successful without innovations in the financial sector, such as e.g. financial instruments the goal of which is to finance and refinance renewable energy sources and enhance energy efficiency. The idea of the green bond market is to develop debt instruments in financing projects contributing to ecologically sustainable development.

The first issue of green bonds, carried out by the European Investment Bank under the name of Climate awareness bonds and worth EUR 600 million, took place on 5 July 2007. It gave rise to a new segment of debt securities (Dziawgo, 2010, p. 78). In 2008, the World Bank (2019), in cooperation with the Swedish bank SEB, issued green bonds. The World Bank, by issuing green debt securities, took up the role of an international issuer (Trompeter, 2017, pp. 4-17). The goal of green bonds issued by the World Bank was to help countries around the world raise capital and finance low-carbon projects to combat air pollution and global climate change (Febi et al., 2018, pp. 53-59). At the end of 2015, the global green debt market reached a cumulative volume of USD 104 billion, whereas the year of 2020 ended at a USD 1.05 trillion total with USD 269.5 billion issued in 2020 alone (Climate Bonds Initiative, 2021).

In the middle of September 2020, the European Commission recommended raising the goal of reduction of greenhouse gas emissions from $40 \%$ to at least $55 \%$ by 2030 . This should enable the European Union to achieve a goal of being climate-neutral by 2050 and fulfill the commitments resulting from the Paris Agreement of 2015.

The aim of this paper is to examine objectives of green bond issues in Europe in particular sectors in the face of adverse climate changes. Taking into account the growing interest of issuers, as well as investors, in green bonds as an instrument of sustainable financing, an analysis of functioning of this market in Europe also was performed. The study concerns only green bond market of corporate issuers, thus it does not cover the issues carried out by states or local government authorities. The selection of this segment of issuers was driven by the growth of popularity of corporate green bonds. Morgan Stanley (2017) describes it as a 'green bond boom'.

The first part of the text presents an overview of the literature on the subject, with particular emphasis on guidelines regarding green bond issues. In the empirical part, an analysis of functioning of the green bond market in Europe was performed, based on the currency of issue, geographic structure, issue period, 
sectors and issue targets. Furthermore, it was examined on which and on how many major stock exchanges the green bonds - active as at 31 December 2020 - were listed.

The article complements the existing literature by focusing on the functioning of the corporate green bond market in Europe.

\section{The essence of green bonds}

Green bonds are debt securities, similar to conventional bonds, which allow for acquiring the capital to be utilized for investments which benefit the environment - mainly projects which contribute to creation of a climate-resistant economy (Flaherty et al., 2017, p. 470). They are also referred to as climate bonds (Cooperman, 2017, pp. 149-150; Lütken, 2015, p. 77). Kaminker \& Steward (2012, p. 35) define green bonds as fixed-income securities issued for financing of infrastructure undertakings related to the low-carbon economy.

Issue of green bonds is subject to similar regulations as bonds issued without a green bond label. However, in the case of green bonds, apart from requirements resulting from statutory provisions, non-statutory requirements shall be added. Debt securities should comply with generally accepted standards of issuing green bonds in order to be regarded as green bond.

International Capital Market Association (ICMA, 2019) defined the requirements of the Green Bond Principles (GBP), under which bonds may be regarded as green bonds. These principles include such criteria as use of proceeds, process for project evaluation and selection, management of proceeds and reporting. Proceeds from the issue of green bonds should be used for projects which contribute to environmental objectives such as: climate change mitigation, natural resource conservation and pollution prevention and control. The process of project evaluation and selection consists in communicating the environmental sustainability objectives by the issuer to investors. The use of proceeds from the green bond issues should be monitored and reflected in the issuer's documents related to its credit and investment policy with respect to green bonds. Furthermore, the principles defined by the IMCA recommend a clear process and disclosure for issuers which investors, banks, placement agents and other entities may use to understand the characteristics of any given green bond. The application of the aforementioned guidelines regarding financing on the green bond market are voluntary. It is the issuer that decides whether a given issue will be carried out in compliance with the guidelines recommended by ICMA. Categories of eligibility for green projects include the following areas: renewable energy, energy efficiency (including for instance energy efficiency in building); pollution prevention and control (including reduction of air emissions, greenhouse gas control); terrestrial and aquatic biodiversity conservation; clean transportation (such as electric, hybrid, public transportation and reduction of harmful emissions); sustainable water and wastewater management; eco-efficient and/or circular economy adapted products, production technol- 
ogies and processes (such as development and introduction of environmentally sustainable products, with an eco-label or environmental certification); green buildings which meet regional, national or internationally recognised standards or certifications.

A need to standardize the green bond market has been also noticed by the Climate Bonds Initiative. The organization set the best practice for labelling green investments - Climate bonds standard (Climate Bonds Initiative, 2019) while enumerating ecological elements of financial projects and assets which should have a direct impact on the development of technology and practices in the area of use of proceeds which contribute to the climate change mitigation. This interpretation leads to extension of the catalog of green debt instruments. The analysis of the literature on the subject also confirms that green bonds should be considered as synonymous with climate bonds (Chiang, 2017, p. 7). The green bonds has a specific investment goal to pursue, namely climate change mitigation or investment into sustainable development (European Commission, 2019). Issue of green label bonds requires undertaking additional activities by the issuer in order to assure the investors that the proceeds from these issues of debt instruments are allocated to environmental projects. These include pre-issuance activities and activities during the issue and spending of proceeds as well as post-issuance activities. Most important pre-issuance requirements of the Climate Bonds Standard are: transparent disclosure of the use of proceeds from the issuance, specifying the process for evaluation and selection of projects and assets, transparent management of proceeds from the issuance, pre-issuance reporting. Post-issuance requirements include documenting by the issuer of the use of proceeds from the issuance, specifying the process for evaluation and selection of projects and assets as well as transparent management of proceeds from the issuance.

The European Commission (2020) also established the EU Green Bond Standard (EU GBS), which was announced in the European Green Deal Investment Plan of 14 January 2020. The most important innovation introduced in the EU GBS, as compared to other standards, is the direct requirement that the proceedings from the EU Green Bonds should finance "green projects", defines as projects which comply with the requirements set out in the EU Taxonomy. The Taxonomy Regulation establishes environmental objectives as: climate change mitigation, climate change adaptation, the sustainable use and protection of water and marine resources, the transition to a circular economy, pollution prevention and control, the protection and restoration of biodiversity and ecosystems.

The issue of green debt instruments entails additional costs which are related to establishing of the Green bond framework, introducing internal processes and structures required for the selection of eligible projects, management of proceeds, monitoring and reporting, as well as obtaining an external opinion. The proceeds from the issuance of green bonds may be used only for financing 
projects which are consistent with the objectives included in the green bond framework.

A government, local government authority, enterprise or financial institution may be issuers of green bonds. They may be issued, among others, as (Brzozowska, 2017, p. 73):

- ordinary bonds (corporate, municipal, government bonds);

- bonds with recourse to the issuer;

- bonds without resource which are secured by proceeds from the project.

Both individual persons, as well as legal entities may be purchasers of green bonds, that is bondholders. These are mainly institutional investors: pension, hedging, investment, life insurance funds and insurance companies.

Climate risk has a significant impact on investors' portfolio companies (Krueger et al., 2020, pp. 1067-1111). Investments into green bonds and traditional bonds produce similar yield. There is no premium on the market for pro-environmental nature of the instrument. Climate Bonds Initiative (2017) studied differences in green bond yields and found no significant differences in the primary market, indicating investors' reluctance to pay a premium for purchasing green bonds. Whereas, the liquidity of green debt securities is lower than for conventional instruments, which is attributable to the size of secondary market and a higher spread of sale and purchase offers.

Green bonds are becoming an investment vehicle that is gaining ground not only among environmentally conscious investors, but also among investors who are aware of the potentially significant impact of the climate. Due to the commitment to transition to a climate resilient economy adopted under the 2015 Paris Climate Agreement, an increasing number of issuers and investors, including investment firms as well as individual investors, are expected to be interested in the green bond market. Selected exchanges created specific segments of the green bond market in order to revitalize this market.

In January 2015, Oslo Børs (Oslo Stock Exchange) was the first stock exchange in the world to launch a separate segment of quotations dedicated to green bonds, that was separated in order to improve visibility of selection of ecological investments. Also other European stock exchanges, such as London Stock Exchange, Luxembourg Stock Exchange, Frankfurt Stock Exchange, have market segments on which green bonds are listed. Services provided by the green bond exchanges include (Erhart, 2018, pp. 10-26): creation of liquid trading market, transparency and disclosure of information (both financial reports and information on financial projects), guidelines regarding the green bonds methodology, developing best practices and creating green indexes. Green bonds are listed on the stock exchange if they meet criteria laid down by the International Capital Market Association. The use of proceedings for projects which do not contribute to the climate improvement or lack of information reporting means the lack of compliance with the requirements and results in removing such instruments from listing in the green bond segment. Stock exchanges should play a key role in promoting the growth of sustainable financ- 
ing (EU, 2019). In addition, they should contribute to improving the liquidity, transparency and reputation of green bonds, increasing the financial resources needed to green the global economy. They should also support the development of green instruments introduced to the market by encouraging compliance with standards.

\section{Research problem}

The presented considerations lead to the definition of the research problem of what are the goals of green bond issues in Europe by particular sectors for the purposes of improving the climate. On this basis, this article verifies the hypothesis that corporate green bonds are more common in industries where the natural environment is of significant financial importance for the operations of enterprises (e.g. industry, energy, technology). As a consequence, the analysis will be useful and helpful in the future research on goals of green bond issues in particular sectors.

\section{Methods}

The analysis of the structure of green bonds in Europe is conducted based on the data included in Refinitiv Eikon (2021) information database. The data set includes corporate green bonds and therefore does not include bonds of government and municipal issuers. To facilitate comparisons, all amounts are in US dollars. Although the green bond market was created around 2007, corporate bonds essentially did not exist in Europe before 2013. In the years 2013-2020, there were 1197 issues of green bonds of corporate entities from the European countries, of the total value of USD 324,427 million.

During the examination process, the author used the method of observation, analysis of source material and a method of deduction.

\section{Green bond market in Europe}

The green bond market is growing rapidly, especially in years 2018-2020. Chart 1 presents the development of corporate green bonds in the years 2013-2020. Over the years there have been a growth of both the value and number of issues of green bonds. While analyzing an average value of issues - the highest value was recorded in 2019 (USD 346.60 million), whereas in 2020 the value of issued green debt is higher than in a previous year and amounts to USD 104,814.50 million, however an average value of issue is lower as compared to 2019 (USD 229.35 million).

The currency structure of green bond issue market in Europe (Chart 2) includes the following currencies: EUR, SEK, USD, GBP and others. EUR $(72.07 \%)$, USD $(9.88 \%)$, SEK $(8.94 \%)$ are main currencies of the issued debt 
securities by corporate issuers from Europe, when measured by the number of issues.

In terms of the value of issued green debt by currencies, EUR is followed by SEK (9.88\%) while USD (8.94\%) holds a third place. An average value of green bond issues in EUR is USD 429.82 million; in SEK - USD 372.86 million, whereas in USD an average value of issue is USD 90.87 million.

In the years 2013-2020, the corporate entities from Europe issued the total of 1127 green bonds. Chart 3 presents the breakdown by countries of issuers' origin. Most green bond issues were carried out by entities from Sweden (341), France (207), Germany (194) and Netherlands (97). This demonstrates the interest of Swedish entities in financing ecological investments. Sweden is considered to be a frontrunner in sustainable finance and in the green bond market. In 2018 green bonds accounted for 10\% of the total SEK bond market (Danske Bank, 2019).

However, in terms of the value of issued green debt, Sweden (USD 29,226 million) comes behind the Netherlands (USD 60,949 million), France (USD 54,678 million) and Germany (USD 35,561 million). Swedish entities, while boasting the biggest number of greed debt issues, have the lowest average value per issue (USD 85.7 million); the lower average value of issue was observed only among the countries in which 3 or less issues took place.

The green bond market is diversified in terms of the structure, allowing greater scope for financing climate solutions. An analysis of the structure of green debt securities market by issue period (Chart 4) indicates that the least number of bonds have maturity of less than 3 years, whereas most instruments have maturity from 3 to 6 years, and the biggest value of green bonds was issued for the tenor from 6 to 9 years, while the highest average value of green debt is observed for the maturity from 9 to 12 years and amounts to USD 410.12 million. The maturity of the issued green bonds by the companies from the energy sector can amount even up to 60 years. Green debt securities for such a tenor were issued by energy companies from Germany — Energie Baden-Wuerttemberg and Portugal - Energias de Portugal. A Danish company Ørsted issued green bonds with 1000 year maturity - all financial instruments have an embedded call option. Furthermore, there were 14 issues of perpetual bonds, all debt securities also have a call option.

While analyzing the coupon type of issued green financial instruments (Table 1), one may notice that 744 green bonds have fixed coupon, which constitutes $62.16 \%$ of all green bond issues by European corporate entities. Other debt instruments have floating coupon (363) as well as discount/zero, range and variable coupon.

Table 2 presents the breakdown of corporate green bonds by sectors. The green debt instruments are more common in industries where the natural environment is of significant financial importance for the operations of enterprises. The highest average value of green bonds was observed in the sectors of Technology (USD 555.91 million) and Utilities (USD 447.45 million). As re- 
gards the number of issues, most issues were carried out in the Financials sector (600). This may result from linking the bond issue with financing certain green projects.

Green bond issue targets in Europe by sector were presented in Table 3 (value of the issue and number of emissions). The highest average value of green bonds have debt securities with the following targets of issue: Renewable Energy Projects (USD 782.96 million), Clean Transportation (USD 378.88 million), Green Construction/Buildings (USD 284.19 million), Energy Efficiency (USD 257.40 million), Alternative Energy (USD 226.82 million) and Eligible Green Projects (USD 207.70 million). Others include Environmental Protection Projects, Aquatic Biodiversity Conservation, Sustainable Water \& Wastewater Management, Land Preservation, Water \& Sewer, Waste Management, Telecom Buildout, Climate Change Adaptation, Pollution Prevention \& Control, Property Expenditure, Environmentally Sustainable Products, Refinance/ Financing expenses, General Purpose/Refinance, Merger or Acquisition, Repay Intercompany Debt, Repay Bank Loan or Bridge Financing. Out of 41 green bond issuances which do not have a specific target of issue of green debt securities, as many as 31 debt instruments were issued by the Financials sector.

Taking into consideration objectives of green bond issues in Europe in particular sectors by number of emission (Table 4) $50.13 \%$ of green bonds were issued by Financials sector, whereas in this sector the main objectives of issue of debt instruments with green label are: Eligible Green Projects (27.33\%), Energy Efficiency (23.83\%) and Clean Transportation (22.67\%). Main objectives of green bond issue in Real Estate sector are: Eligible Green Projects (37.50\%), Green Construction/Buildings (22.27\%) and Energy Efficiency (16.80\%). Whereas in the Utilities sector, main objectives of issue of debt instruments with green label are: Eligible Green Projects (27.38\%), Energy Efficiency (23.21\%) and Clean Transportation (22.02\%), whereas in the Industrial sector it is Eligible Green Projects (39.53\%), and in the Basic Materials sectors also Eligible Green Projects (52.94\%), whereas Energy Efficiency is the main goal in the Energy and Technology sectors. While analyzing the objectives of green bond issues, one may notice that the Eligible Green Projects constitute 31.08\% of the total number of issued instruments. Financing for this purpose is acquired by issuers from Financials and Real Estate sectors. Energy Efficiency is the objective of $22.22 \%$ of green bond issues. Financials sector dominates in this area, which is also the case for the objective of Clean Transportation. In the case of the issue objective of Green Construction/Buildings, 96.72\% issuances were carried out by issues from Financials and Real Estate sectors. The objectives of Renewable Energy Projects and Alternative Energy have 3.43\% share each in the issued green bonds, with Utilities and Financials as the leading sectors in this area.

The Chart 5 presents the number of stock exchanges on which a given issue of green bonds is listed. This applies only to active green bond issues as at 31 December 2020. Approximately 4.7\% active green bonds are not listed on any 
stock exchange, even lower number of issues of green debt instruments is listed on three, four or five stock exchanges. However, an average value of these financial instruments is higher than in the case of green bonds which are not traded on stock exchanges. The highest average value of issues concerns green bonds which are listed on six or more stock exchanges and amounts to USD 774.80 million. Whereas, the highest number of green bonds, that is 470 debt securities with green label, are traded on just one stock exchange, which constitutes the total of $50.37 \%$ of active green debt securities as at 31 December 2020, and their average value is the lowest and amounts to USD 119.68 million. Whereas, issuers of $33.61 \%$ of green debt securities, which are listed on one stock exchange, introduced them to trading on NASDAQ Stockholm $\mathrm{AB}$. Table 5 presents ten major stock exchanges on which green bonds are listed. On the Stuttgart Stock Exchange there are 393 green bonds which are listed on more than one stock exchange. On German stock exchanges, such as Frankfurt Stock Exchange, Munich Stock Exchange, Berlin Stock Exchange and Hannover Stock Exchange, the share of green bonds for which a given stock exchange is the only trading market is below $5 \%$. While on Scandinavian stock exchanges: NASDAQ Stockholm AB and Oslo Stock Exchange, these stock exchanges are the only trading market for over $50 \%$ of issues.

\section{Conclusion}

Green bonds were first issued by the European Investment Bank in 2007 to finance renewable energy and energy efficiency projects. Since then, green bonds have grown in importance as a market-based funding mechanism that contributes to the implementation of the sustainable development strategy.

Growing awareness, of both issuers and investors, of a need to limit adverse climate changes is the reason of interest in sustainable financing instruments. Value of the green bond market, due to many factors, such as for instance pro-environmental nature, will most likely grow. This is demonstrated by stock exchanges on which a separate segment of quotations dedicated to pro-environmental financial instruments were separated.

An analysis of the green bond market in Europe leads to several conclusions. In 2020, despite the COVID-19 pandemics, there was a growth of value of issued green debt, which indicates the growth of demand for green financing. Green instruments issued in EUR currency, with fixed coupon and 3 to 6 year maturity are dominant on the market of European corporate entities. Most issues of green debt securities were carried out by Swedish entities. Green bonds are most common in the industries in which natural environment is important, from the financial point of view, to the operations of enterprises: Utilities, Real Estate, Industrial, Basic Materials, Energy, Technology, which confirms the hypothesis.

Objectives of green bond issues by the European corporate issuers are compliant with the Climate Bond Standard and Green Bond Principles. Proceeds 
from the issue of green bonds are used for such purposes as: Eligible Green Projects, Clean Transportation, Green Construction/Buildings, Renewable Energy Projects and Alternative Energy.

Green bonds, which are listed on one stock exchange have the lowest average value per issue. These are usually Scandinavian stock exchanges NASDAQ Stockholm AB and Oslo Stock Exchange. Whereas, green debt instruments of the highest value per issue, which constitute $24.11 \%$ of the total of active green bonds as at the end of 2020, are listed on six and more number of stock exchanges, whereas - apart from the German stock exchanges - they are most often listed on the stock exchanges in London and Luxembourg.

The results are also of great importance for the participation of Polish companies to act more effectively in the green bond market. They make it possible to define the purposes for which particular industries should obtain green financing. Moreover, both the issuer and the investor benefit from green bonds. By financing pro-ecological projects, the issuer gains the image of a socially responsible organization. Therefore, investors who care about the natural environment choose debt securities of such an issuer. In addition, issuing green bonds is a good way to attract new investors who are climate awareness.

\section{References}

Brzozowska, K. (2017). Idea zrównoważonego rozwoju na rynku obligacji. Prace Naukowe Uniwersytetu Ekonomicznego we Wroctawiu, 478, 70-80. https:// doi.org/10.15611/pn.2017.478.06.

Chiang, J. (2017). Growing the US green bond market: volume 1: the barriers and challenges. Retrieved 01.04.2021 from https://www.treasurer.ca.gov/ greenbonds/publications/reports/l.pdf.

Climate Bonds Initiative. (2017). Green bonds highlights 2016. Retrieved 02.04.2021 from https://www.climatebonds.net/files/files/2016\%20 GB\%20 Market\%20Roundup.pdf.

Climate Bonds Initiative. (2019). Climate bonds standard. Retrieved 02.04.2021 from https://www.climatebonds.net/files/files/climate-bonds-standard-v3-20191210.pdf.

Climate Bonds Initiative. (2021). Record \$269.5bn green issuance for 2020: late surge sees pandemic year pip 2019 total by \$3bn. Retrieved 02.04.2021 from https: / /www.climatebonds.net/2021/01/record-2695bn-green-issuance2020-late-surge-sees-pandemic-year-pip-2019-total-3bn.

Cooperman, E.S. (2017). Managing financial institutions: markets and sustainable finance. Routledge.

Danske Bank. (2019). From 38 to 70bn SEK green bonds are on the rise in Sweden. Retrieved 02.04.2021 from https://danskeci.com/ci/financial-markets/solutions/sustainable-finance/sustainable-finance-news/2019/ from-38-to-70bn-sek-green-bonds-are-on-the-rise-in-sweden. 
Dziawgo, L. (2010). Zielony rynek finansowy: ekologiczna ewolucja rynku finansowego. PWE.

Erhart, S. (2018). Exchange-traded green bonds. Journal of Environmental Investing, $1-41$.

EU. (2019). Report on EU green bond standard. Retrieved 03.04.2021 from https://www.ec.europa.eu/info/sites/info/files/business_economy_euro/ banking_and_finance/documents/190618-sustainable-finance-teg-report-green-bond-standard_en.pdf.

European Commission. (2015). Paris agreement. Retrieved 02.04.2021 from https://www.ec.europa.eu/clima/policies/international/negotiations/ paris_pl.

European Commission. (2019). Europejski zielony tad. Retrieved 03.04.2021 from https://www.ec.europa.eu/info/strategy/priorities-2019-2024/ european-green-deal_pl.

European Commission. (2020). EU taxonomy for sustainable activities. Retrieved 02.04.2021 from https://ec.europa.eu/info/business-economy-euro/banking-and-finance/sustainable-finance/ eu-taxonomy-sustainable-activities_en.

Febi, W., Schafer, D., Stephan, A., \& Sun, C. (2018). The impact of liquidity risk on the yield spread of green bonds. Finance Research Letter, 27, 53-59. https://doi.org/10.1016/j.frl.2018.02.025.

Flaherty, M., Gevorkyan, A., Radpour, S., \& Semmler, W. (2017). Financing climate policies through climate bonds: a three stage model and empirics. Research in International Business and Finance, 42, 468-479. https://doi. org/10.1016/j.ribaf.2016.06.001.

ICMA. (2019). Guidance handbook. Retrieved 02.04.2021 from https://www. icmagroup.org/assets/documents/Regulatory/Green-Bonds/June-2019/ Guidance-Handbook-June-2019-120619.pdf.

Kaminker, C., \& Steward, F. (2012). The role of institutional investors in financing clean energy. OECD Working Papers on Finance, Insurance and Private Pensions, 23, 1-54.

Krueger, P., Sautner, Z., \& Starks, L.T. (2020). The importance of climate risk for institutional investors. The Review of Financial Studies, 33(3), 1067-1111. https://doi.org/10.1093/rfs/hhzl37.

Lütken, S.E. (2015). Financial engineering of climate investment in developing countries. Anthem Press.

Morgan Stanley. (2017). Behind the green bond boom. Retrieved 04.04.2021 from https://www.morganstanley.com/ideas/green-bond-boom.

Refinitiv Eikon. (2021). Retrieved 04.04.2021 from https://www.refinitiv. com/en.

Trompeter, L. (2017). Green is good: how green bonds cultivated into wall street's environmental paradox. Sustainable Development Law \& Policy, 17(2), $1-13$. 
World Bank. (2019). 10 years of green bonds: creating the blueprint for sustainability across capital markets. Retrieved 02.04.2021 from https://www.worldbank.org/en/news/immersive-story/2019/03/18/10-years-of-green-bond s-creating-the-blueprint-for-sustainability-across-capital-markets.

\section{Acknowledgements}

Author contributions: author has given an approval to the final version of the article.

Funding: this research was fully funded by the SGH Warsaw School of Economics, Collegium of Finance and Management statutory sources.

Note: the results of this study were presented at the 8th International Conference Sustainable Finance \& Accounting: Economy, Ethics, Environment (April 19-21, 2021, Torun, Poland). 


\section{Appendix}

Table 1 .

Green bond issues by coupon type

\begin{tabular}{lrr}
\hline \multicolumn{1}{c}{ Coupon type } & Value of the issue (million USD) & Number of emissions \\
\hline discount/zero coupon & $2,576.28$ & 39 \\
fixed coupon & $236,864.06$ & 744 \\
floating coupon & $76,373.62$ & 363 \\
range coupon & $7,278.57$ & 11 \\
unknown & 2.69 & 2 \\
variable coupon & $1,332.22$ & 38 \\
\hline
\end{tabular}

Source: Own preparation based on Refinitiv Eikon (2021).

Table 2.

Structure of the green bond market in Europe by sectors

\begin{tabular}{|c|c|c|}
\hline Sectors & Value of the issue (million USD) & Number of emissions \\
\hline financials & $172,735.27$ & 600 \\
\hline utilities & $75,172.91$ & 168 \\
\hline real estate & $27,602.92$ & 256 \\
\hline industrial & $22,418.17$ & 86 \\
\hline basic materials & $10,014.07$ & 34 \\
\hline consumers cyclicals & $4,850.18$ & 11 \\
\hline energy & $3,318.17$ & 18 \\
\hline technology & $4,447.29$ & 8 \\
\hline others & $3,868.44$ & 16 \\
\hline
\end{tabular}

Source: Own preparation based on Refinitiv Eikon (2021).

Table 3.

Green bond issue targets in Europe by value, by number of emission

\begin{tabular}{lcc}
\hline \multicolumn{1}{c}{ Goals } & Value of the issue (million USD) & Number of emissions \\
\hline clean transportation & $82,595.87$ & 218 \\
eligible green projects & $77,266.88$ & 372 \\
energy efficiency & $68,470.27$ & 266 \\
green construction/buildings & $34,671.34$ & 122 \\
renewable energy projects & $32,101.44$ & 41 \\
alternative energy & $9,299.94$ & 41 \\
general purpose & $5,340.50$ & 38 \\
others & $14,481.19$ & 99 \\
\hline
\end{tabular}

Source: Own preparation based on Refinitiv Eikon (2021). 
Table 4.

Objectives of green bond issues in Europe in particular sectors by number of emission

\begin{tabular}{|c|c|c|c|c|c|c|c|c|c|}
\hline Goals/sectors & $\begin{array}{c}\text { Finan- } \\
\text { cials }\end{array}$ & $\begin{array}{l}\text { Real } \\
\text { estate }\end{array}$ & Utilities & $\begin{array}{c}\text { Indus- } \\
\text { trial }\end{array}$ & $\begin{array}{l}\text { Basic } \\
\text { mate- } \\
\text { rials }\end{array}$ & Energy & $\begin{array}{l}\text { Tech- } \\
\text { nology }\end{array}$ & $\begin{array}{l}\text { Con- } \\
\text { sumers } \\
\text { cyclicals }\end{array}$ & Others \\
\hline eligible green projects & 164 & 96 & 46 & 34 & 18 & 2 & 3 & 3 & 6 \\
\hline energy efficiency & 143 & 43 & 39 & 15 & 6 & 7 & 6 & 1 & 6 \\
\hline clean transportation & 136 & 24 & 37 & 13 & 1 & 1 & 1 & 3 & 2 \\
\hline green construction/buildings & 61 & 57 & 1 & 2 & & 1 & & & \\
\hline renewable energy projects & 17 & & 15 & 7 & & 2 & & & \\
\hline alternative energy & 16 & 1 & 16 & 2 & 2 & 3 & & 1 & \\
\hline general purpose & 13 & 19 & 1 & 3 & 1 & 1 & & & \\
\hline others & 50 & 16 & 13 & 10 & 6 & 1 & 1 & & 2 \\
\hline
\end{tabular}

Source: Own preparation based on Refinitiv Eikon (2021).

\section{Table 5.}

Ten major stock exchanges on which green bonds are listed

\begin{tabular}{lcc}
\hline Name of the stock exchange & Only listed on l stock exchange & Listed on more than l stock exchange \\
\hline Stuttgart Stock Exchange & 74 & 393 \\
Frankfurt Stock Exchange & 11 & 355 \\
NASDAQ Stockholm AB & 158 & 270 \\
Munich Stock Exchange & 4 & 235 \\
London Stock Exchange PLC & 16 & 231 \\
Berlin Stock Exchange & 1 & 208 \\
Luxembourg Stock Exchange & 34 & 194 \\
Irish Stock Exchange & 75 & 179 \\
Hannover Stock Exchange & 4 & 98 \\
Oslo Stock Exchange & 43 & 78 \\
\hline
\end{tabular}

Source: Own preparation based on Refinitiv Eikon (2021). 
Chart 1.

Green bond issues by value (in million USD), by number of emission in 2013-2020 500

457

120000

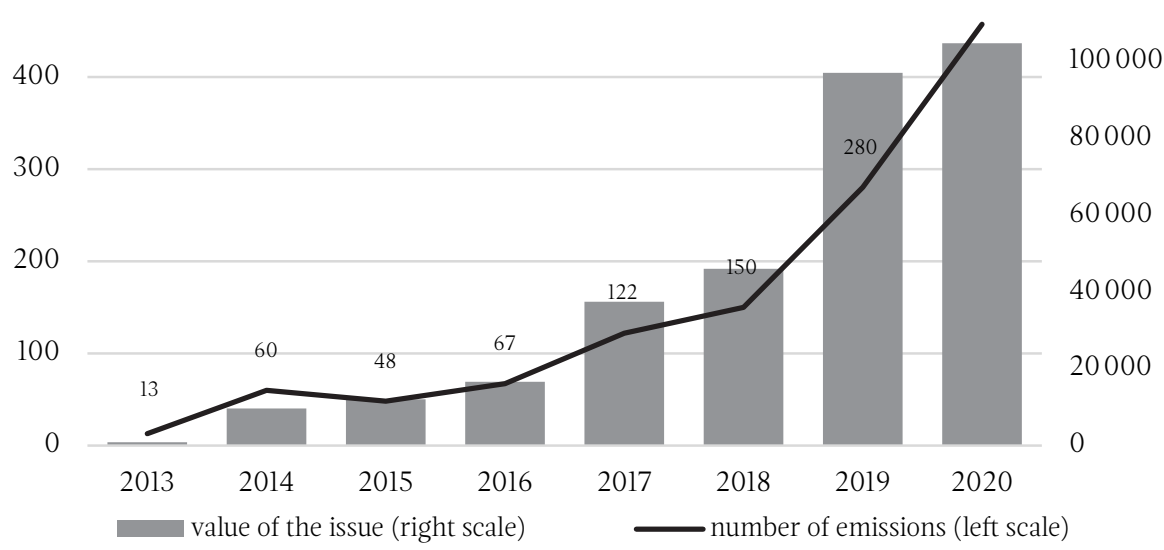

Source: Own preparation based on Refinitiv Eikon (2021).

Chart 2.

Green bond issues by currency in 2013-2020 (in million USD)

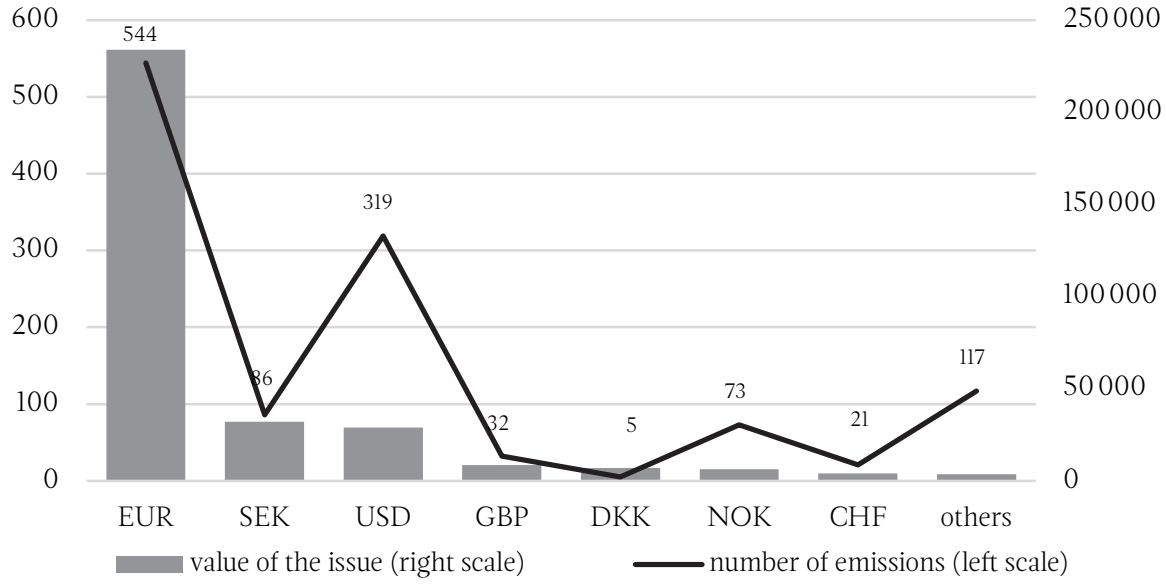

Source: Own preparation based on Refinitiv Eikon (2021). 
Chart 3.

Green bond issues by country in 2013-2020(in million USD)

400 341

80000

300

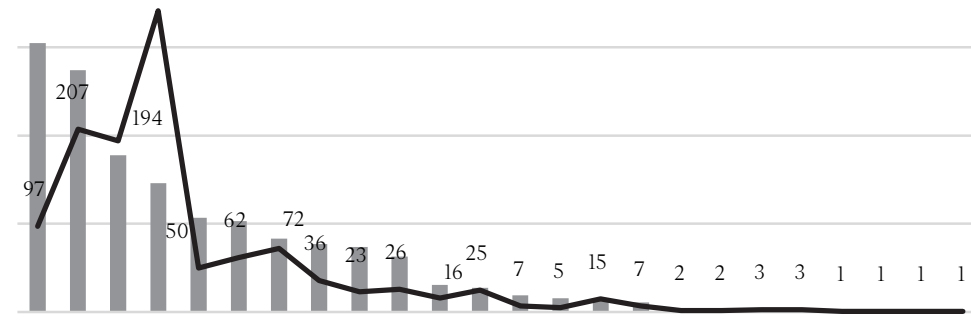

60000

40000

20000

0

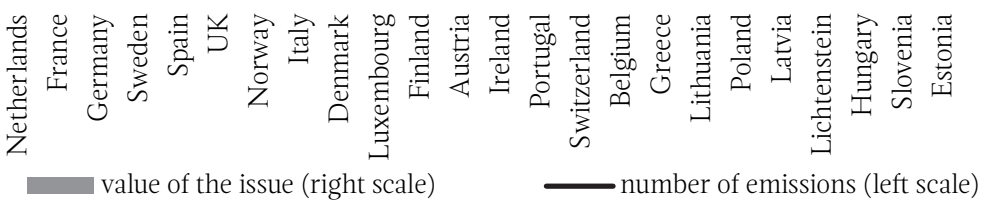

Source: Own preparation based on Refinitiv Eikon (2021).

\section{Chart 4.}

Green bond issues by issue period (in years) (in million USD)

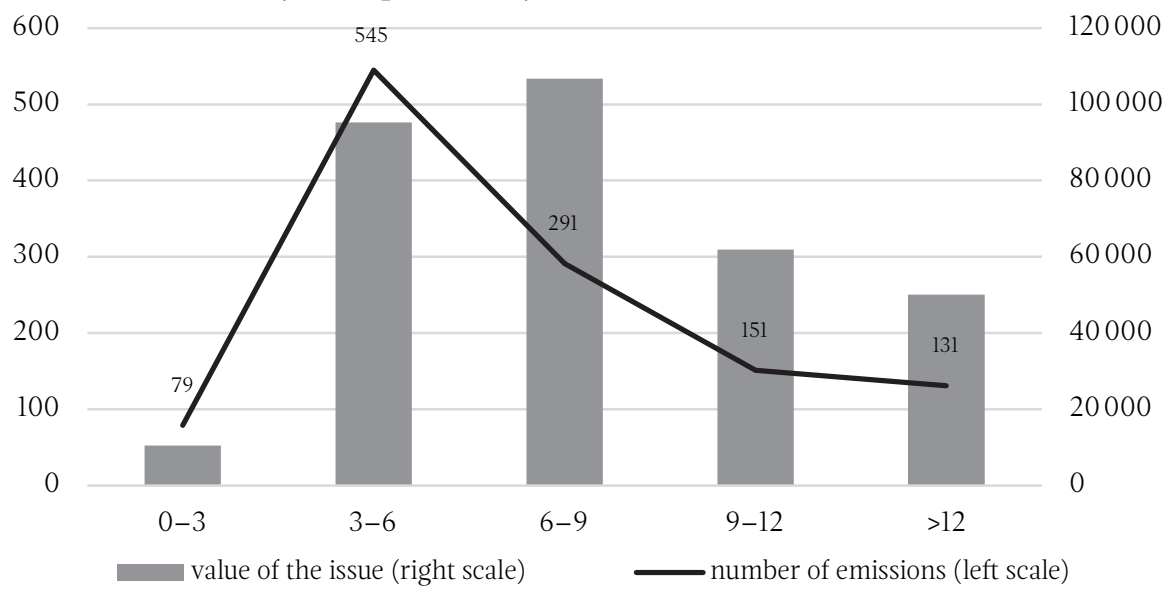

Source: Own preparation based on Refinitiv Eikon (2021). 


\section{Chart 5.}

The number of stock exchanges on which a given issue of green bonds is listed(in million USD)

500

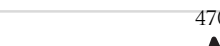

40

00

300


2

average value of the issue (right scale) 800

Source: Own preparation based on Refinitiv Eikon (2021). 
